\title{
HUBUNGAN KEKERABATAN BAHASA BARANGAS DAN BAHASA BAKUMPAI DI KALIMANTAN SELATAN
}

\section{THE KINSHIP RELATIONSHIP OF BARANGAS LANGUAGE AND BAKUMPAI LANGUAGE IN SOUTH KALIMANTANS}

\author{
Siti Jamzaroh
}

Balai Bahasa Kalimantan Selatan

Ponsel: 08 81254216436; Pos-el: siti.jamzaroh@kemdikbud.go.id

Penelitian ini bertujuan untuk (1) mendeskripsikan hubungan kekerabatan bahasa Barangas dan bahasa Bakumpai dan (2) mengetahui perubahan bunyi yang terjadi pada kedua bahasa tersebut. Metode penelitian meliputi pengumpulan data, pengolahan data, dan analisis data. Pengumpulan data dilakukan dengan instrumen daftar 200 kosakata Swadesh dan kosakata budaya, pengolahan data dengan metode leksikostatistik, analisis data dengan teknik banding-padan. Teori yang digunakan adalah kajian linguistik komparatif dan leksikostatistik. Hasil yang ditemukan:1) hubungan kekerabatan bahasa Barangas dan bahasa Bakumpai memiliki derajat retensi sebesar $75 \%$ dari bahasa protonya dan 2) tipe perubahan bunyi yang terjadi adalah i) pelemahan atau penguatan bunyi (lenition-fortition), dan ii) penghilangan bunyi di awal kata (apheresis) dan penghilangan bunyi di akhir kata (apokop).

Kata-kata kunci: hubungan kekerabatan; leksikostatistik; kosakata swadesh

\begin{abstract}
This study aims at (1) describing the kinship between the Barangas language and Bakumpai language and (2) knowing the sound changes that occur in both languages. Research methods include data collection, data processing, and data analysis. Data collection is performed by occupying 200 Swadesh vocabulary and cultural vocabulary instruments, data processing is using the lexicostatistic method, and data analysis is using comparative matching techniques. The theory used is comparative and lexicostatistic linguistic studies. The results shows that: 1) The kinship between the Barangas language and Bakumpai language has a retention degree of $75 \%$ of the proton language and 2) the type of sound changes that occur are i) sound weakening or strengthening (lenition-fortition), and ii) the disappearance of the sound at the beginning of the word (apheresis) and the removal of the sound at the end of the word (apocopy).
\end{abstract}

Keywords: kinship relations; lexicostatistics; swadesh vocabulary 


\section{Pendahuluan}

Salah satu cabang linguistik yang mengkaji bahasa-bahasa dalam kaitannya dengan hubungan kekerabatan bahasa adalah lingistik historis komparatif. Antila (1972:72) mengatakan bahwa tugas utama linguistik historis komparatif adalah menetapkan fakta dan tingkat kekerabatan antarbahasa yang berkaitan erat dengan pengelompokkan bahasa-bahasa sekerabat.

Selain bahasa-bahasa yang ada di pulau Jawa, para ahli bahasa mulai tertarik meneliti bahasa-bahasa di Kalimantan, di antaranya bahasa Banjar sebagai salah satu isolek Melayu. Kajian kemudian diperluas dengan meneliti bahasa-bahasa Dayak. Para ahli bahasa yang mengawali penelitian bahasa-bahasa di Kalimantan antara lain Collins (2005), Adelaar (1994), Wolff (1988), dan lain-lain.

Kalimantan Selatan telah lama menjadi objek penelitian keragaman bahasa daerah. Selain bahasa Banjar sebagai bahasa pergaulan, penutur asli bahasa-bahasa daerah yang lain masih dapat ditemukan meski penggunaannya dalam forum yang terbatas. Bahasa-bahasa tersebut adalah bahasa Maanyan, bahasa Dayak Halong, bahasa Dayak Dusun, bahasa Deyah, bahasa Bakumpai, Bahasa Barangas, dan lain-lain. Bahasa-bahasa tersebut masih dipakai penuturnya dalam kehidupan sehari-hari.

Bahasa Bakumpai merupakan sebuah bahasa yang dipakai oleh masyarakat di wilayah Kalimantan Selatan, tepatnya di kota Maraban, Kabupaten Barito Kuala. Cense dan Uhlenbeck (1958) tidak menyinggung keberadaan bahasa Bakumpai, demikian pula bahasa Barangas. Sementara itu, Hudson (1967) menyinggung keberadaan bahasa Bakumpai sebagai dialek Dayak Ngaju. Hal ini dikuatkan oleh Riwut (1979) yang menyatakan bahwa bahasa Bakumpai sebagai dialek bahasa Dayak Ngaju.

Kajian yang berkaitan dengan bahasa Bakumpai antara lain kajian yang dilakukan Aritonang (2002), Yayuk (2009), Jahdiah, dkk (2012), dan Misrita (2016). Jahdiah menyimpulkan bahwa dalam bahasa Barangas dan bahasa Banjar terdapat 34 kosakata yang sama dan 35 kosakata yang mirip. Selain itu, berdasarkan perhitungan dialektrometri, bahasa Banjar dan bahasa Barangas memiliki persentase dialektrometri $82 \%$,

Mengenai bahasa Bakumpai, bahasa ini bukan hanya ada di Kalimantan Selatan, tetapi juga ada di Kalimantan Tengah. Penelitian ini hanya mengambil data enklave bahasa Bakumpai di 


\section{Jamzaroh}

Kalimantan Selatan. Mengenai kedekatannya dengan bahasa Banjar, Misrita (2016) berpendapat bahwa pengaruh Melayu Banjar pada enklave bahasa Bakumpai di Marabahan sangat kuat, terutama sekali dalam pemakaian bahasanya karena bahasa Melayu Banjar sebagai bahasa lingua franca digunakan dalam perdagangan, sedangkan bahasa Bakumpai hanya digunakan dalam lingkungan keluarga.

Terkait bahasa Berangas, kata "Barangas" atau Berangas ditengarai diambil dari nama desa yang terletak di perbatasan Kota Banjarmasin dan Kabupaten Barito Kuala. Penutur bahasa Barangas dipisahkan oleh sungai Alalak yang bermuara di sungai Barito. Mereka sebagian berdomisili di sebelah kiri dan kanan sungai tersebut, satu wilayah yang berada di Kabupaten Barito Kuala dan satu wilayah berada di Kotamadya Banjarmasin, tepatnya di Kecamatan. Alalak Utara, Banjarmasin Utara. Mereka hidup berdampingan dengan masyarakat Banjar di sekitarnya. Penutur bahasa Barangas merupakan salah satu dari beberapa etnis asli Kalimantan Selatan yang mengalami ancaman kepunahan identitas. Kepunahan bukan disebabkan faktor alam, tetapi sebagian besar penutur bahasa Barangas yang telah memeluk
Islam meninggalkan adat istiadat dan bahasanya sedikit demi sedikit. Kenyataan seperti ini juga terjadi pada bahasa Dayak lainnya yang mulai ditinggalkan penuturnya karena mereka berpindah menjadi pemeluk agama Islam. Selanjutnya, mereka lebih suka mengubah identitasnya menjadi orang Banjar. Mereka tidak mempertahankan adat istiadat, budaya, dan bahasa mereka sendiri. Berdasarkan kajian Hapip dkk. (1984:4), penutur bahasa Barangas yang berkedudukan di Kalimantan Selatan memiliki enklave atau kantung-kantung bahasa Barangas yang berpusat di Kabupaten Barito Kuala, antara lain Desa Alalak, Desa Balandean, Tabunganen, Sungai Teras. Selain di Kelurahan Alalak Utara, bahasa Barangas juga ditemukan di Desa Aluh-Aluh, Kabupaten Banjar. Namun, sampai saat ini keberadaan bahasa Barangas di Kabupaten Banjar tersebut belum dapat diidentifikasi perkembangannya.

Kajian perbandingan bahasa Bakumpai dan bahasa Barangas ini ditujukan untuk mengetahui keterkaitan bahasa Bakumpai dan bahasa Barangas. Fernandez (1995:29) menegaskan bahwa pengelompokan bahasa terbagi atas pengelompokan bahasa makro dan mikro. Pengelompokkan bahasa makro diartikan 
sebagai pengelompokkan bahasa kerabat yang cakupan penjelasannya mengenai hubungan antarbahasa serumpun, diamati secara khusus pada tingkat yang lebih tinggi atau pada tingkat atas (dalam kaitannya dengan pengelompokkan suatu bahasa serumpun yang lebih luas dan menyeluruh). Dengan demikian, tujuan penelitian adalah 1) mengetahui hubungan kekerabatan bahasa Barangas dan bahasa Bakumpai yang merupakan bahasa sekerabat dan 2) perubahan bunyi apa saja yang terjadi antarbahasa tersebut.

Data primer penelitian ini diperoleh dari informan kedua bahasa yang diteliti, yakni bahasa Barangas dan bahasa Bakumpai. Informan yang dipakai adalah penutur asli bahasa Barangas dan bahasa Bakumpai, berusia 60--70 tahun, tidak atau jarang bepergian jauh, memiliki alat ucap yang masih lengkap, dan masih fasih menggunakan bahasa Barangas dan Bakumpai dalam kehidupan sehari-hari. Informan penutur bahasa Bakumpai adalah penutur asli bahasa Bakumpai yang berasal dari Desa Marabahan Kota, Kecamatan Bakumpai, Kabupaten Barito Kuala. Data sekunder diperoleh dari penelitian terdahulu, yakni penelitian yang dilakukan oleh Yayuk (2009), dan Aritonang (2002). Sebagai bahan referensi, dipergunakan Kamus Dwi
Bahasa Dayak Ngaju-Indonesia yang disusun Bingan dkk (1997), Kamus Bakumpai-Indonesia yang disusun oleh Kawi (1985), dan Kamus Bahasa Melayu Maleisch-Nederlandsch Zakwoordenboek yang disusun oleh Klinkert (1918).

\section{Landasan Teori}

\subsection{Kajian Linguistik Historis Komparatif}

Pengelompokkan bahasa dalam

rangka kajian linguistik diakronis biasa dikenal dengan istilah klasifikasi genealogis (genetis) atau subgrouping bahasa. Dalam hal ini, pengelompokkan bahasa sering kali dikaitkan dengan dengan pembagian rumpun bahasa, seperti rumpun bahasa Indo-Eropa, Astro Asia, Austronesia, atau Melayu Polynesia, dan sebagainya.

Fernandez (1996) menjelaskan masalah hubungan antarbahasa sekerabat dalam telaah komparatif pada prinsipnya dapat dibuktikan berasarkan unsur-unsur warisan dari bahasa asal atau protobahasa (proto language). Proto bahasa sebagaimana dikatakan oleh Bynon (1979) tidak lain adalah gagasan teoretis yang dirancang atas cara yang amat sederhana guna menghubungkan sistem-sistem bahasa sekerabat dengan memanfaatkan sejumlah kaidah. 
Jamzaroh

Linguistik historis komparatif atau linguistik bandingan historis menggunakan kesamaan bentuk dan makna sebagai pantulan dari sejarah warisan yang sama. Keraf (1991:34) menjelaskan bahwa bahasa-bahasa kerabat yang berasal dari bahasa proto yang sama selalu akan memperlihatkan kesamaan-kesamaan

1) kesamaan sistem bunyi (fonetik) dan susunan bunyi (fonologis); 2) kesamaan morfologis, yaitu kesamaan bentuk kata dan kesamaan bentuk gramatikal; 3) kesamaan sintaksis, yaitu kesamaan relasi antara kata-kata dalam sebuah kalimat.

\subsection{Leksikostatisitik}

Crowley (1997:168--169) mengatakan bahwa leksikostatistik adalah teknik yang digunakan untuk menentukan hubungan dua bahasa dengan hanya membandingkan kosakata bahasa-bahasa tersebut dan menentukan kadar kemiripan di antara bahasa-bahasa tersebut. Metode ini digunakan untuk mengelompokkan bahasa-bahasa dengan data yang terbatas.

Mengacu pada pendapat Crowley (1997:93), langkah-langkah analisis leksikostatistik adalah sebagai berikut:

(1) Mempersiapkan 200 kosakata dasar Swadesh dua bahasa yang diperbandingkan; dan
(2) Menentukan kata-kata berkognat, yakni kata-kata yang memiliki bentuk yang mirip dan makna yang sama.

Pada tahapan ini, perlu dipertimbangkan kosakata yang merupakan pinjaman dari bahasa lain atau kosakata yang mendapat tambahan morfem tambahan melalui proses morfologis. Kosakata pinjaman harus digugurkan dan morfem tambahan yang dapat mengacaukan perbandingan harus ditanggalkan terlebih dahulu (glos yang tidak diperhitungkan karena alasan tersebut).

Langkah-langkah berikutnya yang dilakukan adalah

(a) Mencari korespondensi vokal berupa korespondensi bunyi vokal dan konsonan. Korespondensi bunyi merupakan dasar untuk menentukan hubungan kekerabatan antarbahasa. Walaupun kosakata dasar sangat jarang mengalami pinjaman, namun korespondensi bunyi harus dilakukan dengan hati-hati agar tidak terjebak korespondensi dalam kata pinjaman yang tidak terdeteksi (Campbell, 1998:313--324).

Selain korespondensi bunyi, bukti-bukti morfologis dapat melengkapi bukti penentuan kekerabatan bahasa. Hipotesa 
mengenai kekerabatan terkuat adalah korespondensi bunyi dalam kosakata dasar yang dilengkapi dengan contoh bentuk gramatikal dan proses morfologis.

(b) Melakukan penghitungan persentase kekerabatan berdasarkan jumlah katakata kognat dan kosakata dasar yang tersisa untuk menentukan hubungan antarbahasa tersebut berdasarkan tingkat pengelompokkan berikut. Jumlah kata hasil temuan tersebut kemudian dihitung persentasenya dibandingkan $200 \quad$ kosakata. Persentase yang ditemukan lalu dicocokkan dengan tabel

leksikostatistik berikut ini.

\section{Tabel 1}

Pengelompokkan Bahasa Berdasarkan Leksikostatistik

$\begin{array}{lll}\begin{array}{l}\text { Tingkatan } \\ \text { Bahasa }\end{array} & \begin{array}{l}\text { Waktu pisah } \\ \text { dalam abad }\end{array} & \begin{array}{l}\text { Persentase } \\ \text { Kata } \\ \text { Kerabat } \\ 100-81\end{array} \\ \begin{array}{l}\text { Bahasa } \\ \text { (language) }\end{array} & 0-9 & 81--36 \\ \begin{array}{l}\text { Keluarga } \\ \text { family) }\end{array} & 5-25 & 36-12 \\ \text { Rumpun } & 25-50 & 12--4 \\ \text { Mikrofilum } & 50-75 & 4--1 \\ \text { Mesofilum } & 75-100 & 1--0\end{array}$

Sumber: Crowley (1997:170); Keraf (1991:135)

Tahap berikutnya adalah penganalisisan data dengan membandingkan kata-kata yang diklasifikasikan sebagai kosakata yang mirip, sepadan, atau sama untuk melihat gejala perubahan yang terjadi di antara kedua bahasa tersebut.

\subsection{Tipe- Tipe Perubahan Bunyi}

Crowley (1997:36--57) mengidentifikasi tipe-tipe perubahan bunyi yang bisa terjadi pada bahasa sekerabat maupun tidak sekerabat. Perubahan bunyi tersebut menimbulkan variasi bunyi yang berkembang dalam setiap bahasa tersebut. Tipe-tipe perubahan tersebut antara lain pelemahan bunyi dan penguatan bunyi (lenition and fortition), penghilangan bunyi (apokopo, sinkop, apheresis, dll) penambahan bunyi (sound addition, (meliputi protesis, methathesis, dll), penggabungan bunyi (fussion), pemecahan vokal (vowel breaking), unpacking, asimilasi (assimilation), disimilasi (disimilasiton), dan perubahan bunyi yang tidak teratur (abnormal sound change).

\section{Metode Penelitian}

Menurut Mahsun (2011:163), metode yang bisa dilakukan pada penelitian ini bertumpu pada tiga asumsi dasar, yakni (1) sebagian kosakata dalam suatu bahasa sukar berubah bila dibandingkan dengan yang lainnya. Kosakata yang sukar berubah itu disebut kosakata dasar (basic vocabulary) yaitu kosakata yang bersifat universal (terdapat di semua bahasa); (2) Retensi atau ketahanan kosakata dasar adalah konstan 


\section{Jamzaroh}

sepanjang masa. Menurut asumsi ini, bahwa dalam seribu tahun, kosakata dasar untuk semua bangsa berganti sekitar 20 persen; (3) Perubahan yang terjadi pada semua kosakata dalam suatu bahasa adalah sama.

Pengumpulan data dilakukan dengan menggunakan daftar 200 kosakata Swadesh yang dibuat oleh Morrish Swadesh, dan Daftar Holle yang memuat 1500 kata (data pendukung). Daftar kosakata Swadesh tersebut (hasil revisi Blust 1980) berisi kosakata dasar (basic vocabulary) yang dimiliki oleh semua bahasa.

Pengolahan data dilakukan dengan mengklasifikasan kosakata yang mirip, sepadan, atau sama; dan memisahkan kosakata yang ditengarai sebagai kata pinjaman. Kosakata tersebut kemudian dihitung dan dikalikan $100 \%$ sehingga didapatkan persentase kekerabatan hubungan yang sesuai dengan pengelompokkan leksikostatistik.

Tahap berikutnya adalah penganalisisan data dengan membandingkan kata-kata yang diklasifikasikan sebagai kosakata yang mirip, sepadan, atau sama untuk melihat gejala perubahan yang terjadi di antara kedua bahasa tersebut.

\section{Pembahasan}

\subsection{Hubungan Kekerabatan Bahasa Barangas dan Bakumpai}

Dalam perhitungan leksikostatistik selama ini, data yang diperbandingkan dianalisis sebanyak 200 kosakata Swadesh. Bahkan sebuah penelitian yang ekstrim yang dilakukan oleh Suyata (1995), hanya dibutuhkan 100 buah kosakata Swadesh. Hal ini menunjukkan bahwa penelitian kuanitatif hanya memerlukan sedikit kosakata untuk membuktikan adanya hubungan kekerabatan kedua bahasa yang diperbandingkan.

Keterkaitan bahasa Barangas dan bahasa Bakumpai pada dasarnya dapat dilihat atau diketahui dari banyaknya kognat atau kepemilikan bersama kosakata dari kosakata yang diperbandingkan. Kognat menandai kedekatan hubungan kekerabatan antardua bahasa yang diperbandingkan. Berdasarkan analisis yang telah dilakukan atas 200 kosakata Swadesh, ditemukan beberapa hal berikut ini.

\subsubsection{Glos yang tidak diperhitungkan}

Beberapa glos yang tidak diperhitungkan dalam perbandingan antara lain merupakan kata pinjaman dari bahasa lain; tidak ada padanannya; atau terdapat glos yang maknanya sama pada salah satu bahasa yang diperbandingkan. Adanya 
kata pinjaman dalam bahasa Barangas dan bahasa Bakumpai mengacu pada kamus bahasa Dayak Ngaju, Kamus bahasa Bakumpai-Indonesia (Kawi, 1985) dan kamus bahasa Melayu MaleischNederlandsch Zakwoordenboek (Fernandez, 1995). Dengan demikian, dapat ditentukan mana kosakata bahasa asli bahasa Dayak dan mana kosakata pinjaman dari bahasa lain, khususnya dari bahasa Jawa, Melayu Banjar, bahasa Belanda, dan lain-lain.

Berikut adalah beberapa glos yang tidak diperhitungkan dalam bahasa Barangas dan bahasa Bakumpai.

1) Kata-kata pinjaman sejumlah 2 buah, yakni glos reken (87) (bahasa Belanda), glos 'kotor' rigat (bahasa Jawa rəgət) (115).

2) Pasangan kata yang berkonsep sama yang muncul dalam bentuk yang sama sehingga hanya diperlukan satu bentuk untuk dibandingkan. Kata tersebut adalah buruk untuk glos buruk dan busuk, dan bujur untuk glos lurus dan benar (137). Glos yang diperhitungkan adalah buruk (42) dan benar (25).

3) Kata-kata yang tidak ada padanannya antara lain glos ular (199), tumpul (195), tiup (194), tipis (193), tikam (192), tidak (189), terbang (186), tebal (183), tajam (177), tahu (175), semиa
(170), sempit (170), perut (156), mereka (141), karena (107), kabut (102), lempar (126), leher (124), lain (120), kulit (117), berkelahi (111), kata (109), karena (108), kanan (107), kabut (102) ikat (93), ia (90), hutan (89), hisap (85), hapus (80), gosok (77), gigit (76), debu (55), daun (53) buru (41), cium (46), binatang (35), besar (32), benih (27), belah (24) balik (17), baru (20), apung (11) apa, (8) alir (me) (4), abu (1).

Berdasarkan tabel perhitungan leksikostatistik, diketahui bahwa hubungan kekerabatan tertinggi antarbahasa Barangas dan Bakumpai yang diperbandingkan adalah sebesar $75 \%$. Artinya bahasa Barangas dan bahasa Bakumpai termasuk dalam kategori bahasa sekerabat $(37 \%--80 \%)$,

Hasil perhitungan tersebut menguatkan dugaan sementara bahwa sebenarnya bahasa Barangas bukanlah "bahasa", melainkan enklave bahasa Bakumpai yang terletak di wilayah perbatasan Kabupaten Barito Kuala dan Kotamadya Banjarmasin. Simpulan ini dikuatkan dengan fakta yang terdapat di lapangan bahwa enklave bahasa Bakumpai terdapat di wilayah Kalimantan Tengah, Kalimantan Selatan di Kabupaten Barito Kuala, dan bahasa Barangas hanya 
terdapat di sepanjang sungai Barito yang mengalir hingga ke Kabupaten Banjar.

\subsubsection{Penetapan Kata Kerabat}

4.1.2.1 Kata Bilangan

Tabel 2

Kata Bilangan

\section{Bahasa Barangas dan Bakumpai}

\begin{tabular}{|c|c|c|c|c|}
\hline No. & Glos & Barangas & & Bakumpai \\
\hline 1. & satu & $i j \varepsilon^{\prime}$ & $\approx$ & $i j \varepsilon$ \\
\hline \multirow[t]{2}{*}{2.} & dua & $d u w \varepsilon^{\prime}$ & $\approx$ & duwe \\
\hline & empat & epat & $\approx$ & cpat \\
\hline 4. & lima & $\lim \varepsilon^{\prime}$ & $\approx$ & lime \\
\hline 5. & tiga & telo & $\approx$ & telu \\
\hline 6. & enam & jahawen & $\approx$ & jahawen \\
\hline 7. & tujuh & $u j u^{\prime}$ & $\approx$ & huju \\
\hline 8. & delapan & haňa & $\approx$ & haña \\
\hline 9. & sembilan & jalaticn & $\approx$ & jalaticn \\
\hline
\end{tabular}

Kata bilangan dasar kedua bahasa tersebut memperlihatkan kemiripan. Hal ini berarti bahwa kedua bahasa tersebut masih pempertahankan kosakata dari bahasa induknya.

Kata bilangan, baik bahasa Barangas maupun bahasa Bakumpai samasama hanya mengenal penyebutan sembilan angka bilangan, yakni ije, duwe, telu, epat, lime, jahawen, uju, haña dan jalatien. Selebihnya, bilangan kelipatan sepuluh menggunakan bahasa Melayu (Banjar).

\subsubsection{Kata Ganti}

\section{Tabel 3}

Kata Ganti

\section{Bahasa Barangas dan Bakumpai}

$\begin{array}{llll}\text { No. } & \text { Glos } & \text { Barangas } & \text { Bakumpai } \\ \text { 1. } & \text { saya } & \text { Yaku } & \approx \text { yaku } \\ \text { 2. } & \text { engkau Ikaw } & \text { ikaw } \\ \text { 3. } & \text { kami/kita } & \text { itih, itah } \approx \text { itih,itah } \\ \text { 4. } & \text { kamu } & \text { ikaw } & \text { Ikaw }\end{array}$

Kata ganti orang ketiga, baik tunggal maupun jamak bahasa Barangas tidak lagi sama dengan bahasa Bakumpai. Kata ganti orang ketiga tunggal/jamak Bakumpai iyelawen (bahasa Ngaju iya/cwen) dan Berangas iña/bubuhan (bahasa Banjar iña/bubuhan). Ini merupakan bukti adanya pengaruh bahasa Banjar dalam bahasa Barangas.

\subsubsection{Anggota Tubuh}

Seperti halnya kata bilangan dan kata ganti orang, kata anggota tubuh juga sulit berubah.

\section{Tabel 4 \\ Anggota Tubuh}

Bahasa Barangas dan Bakumpai

\begin{tabular}{|c|c|c|c|c|}
\hline No. & Glos & Barangas & & Bakumpai \\
\hline 1. & gigi & kasiye' & $\approx$ & kasine \\
\hline 2. & hidung & uruy & $\approx$ & Uruy \\
\hline 3. & kaki & payi' & $\approx$ & Pay \\
\hline 4. & kepala & takuluk & $\approx$ & Takuluk \\
\hline 5. & kuku & ilu’' & $\approx$ & silu’ \\
\hline 6. & lidah & jila' & $\approx$ & jile \\
\hline 7. & mata & $m a t i^{\prime}$ & $\approx$ & mate \\
\hline 8. & lutut & hitut & $\approx$ & Tut \\
\hline
\end{tabular}



9. rambut balaw $\approx$ balau
10. tangan leye' $\approx$ ley $\varepsilon^{\prime}$
11. telinga pindiy $\approx$ pindiy
12. tulang tulay $\approx$ tulay

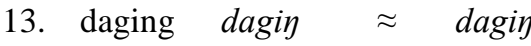
14. bibir biwih $\approx$ biwih

Dari data-data di atas, dapat dikatakan bahwa kesepadanan antarbahasa Barangas dan bahasa Bakumpai dimungkinkan karena adanya pengaruh perubahan bunyi yang didasarkan pada lingkungan fonem yang berada pada posisi yang sama.

Berdasarkan data di atas, kosakata yang berhubungan dengan anggota tubuh tidak menunjukkan adanya perubahan. Hal ini menjadi bukti pendukung bahwa kedua bahasa tersebut memiliki kedekatan hubungan kekerabatan. Selanjutnya, bahasa Barangas dan Bakumpai memiliki kemiripan dalam penyebutan kata bilangan yang sama. Beberapa kata bilangan menunjukkan perbedaan pelafalan, seperti tclo-tclu, uju'-huju yang dianggap sebagai variasi wicara saja tanpa mengubah maknanya. Demikian pula pada kata ganti persona, glos kami/kita, bahasa Barangas memiliki itih/itah yang menyerupai kita dalam bahasa Melayu. Hal ini bukan berarti bahwa bahasa Barangas dan bahasa Bakumpai meminjam bahasa Melayu Banjar.

\subsubsection{Pasangan Kata yang Sepadan (Kognat) \\ Berikut ini ditampilkan pasangan} kata bahasa Barangas dan bahasa Bakumpai yang sepadan (berkognat).

\section{Tabel 5}

Pasangan Kata Kognat

\section{Bahasa Barangas dan Bakumpai}

No.

\begin{tabular}{|c|c|c|c|c|}
\hline 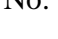 & Glos & Barangas & & Bakumpai \\
\hline 1. & air & Danum & $\approx$ & danum \\
\hline 2. & akar & uhat & $\approx$ & uhat \\
\hline 3. & anak & Anak & $\approx$ & anak \\
\hline 4. & angin & Anin & $\approx$ & ayin \\
\hline 5. & anjing & $a s u^{\prime}$ & $\approx$ & asu \\
\hline 6. & api & apoy' & $\approx$ & apuy \\
\hline 7. & asap & anscp & $\approx$ & anscp \\
\hline 8. & awan & Awan & $\approx$ & awan \\
\hline 9. & ayah & Bapa & $\approx$ & apa \\
\hline 10. & $\begin{array}{l}\text { bagaima } \\
\text { na }\end{array}$ & $\begin{array}{l}\text { kakuweh } \\
\text { yo? }\end{array}$ & $\approx$ & $\begin{array}{l}\text { kilawkuwe } \\
h\end{array}$ \\
\hline 11. & baik & Bagus & $\approx$ & bagus \\
\hline 12 & bakar & Inosol & $\approx$ & nusul \\
\hline 13.' & banyak & a'ari & & $\operatorname{arc}$ \\
\hline 14. & baring & $m \varepsilon n t \varepsilon R$ & $\approx$ & menter \\
\hline 15. & basah & babisa' & $\approx$ & babisa' \\
\hline 16. & batu & Batu & $\approx$ & batu \\
\hline 17. & $\begin{array}{l}\text { belah } \\
\text { (me) }\end{array}$ & nila' & $\approx$ & mañila' \\
\hline 18. & berat & babchat & $\approx$ & babchat \\
\hline 19. & berenang & Hanayuy & $\approx$ & hanayuy \\
\hline 20. & beri & maneya' & $\approx$ & neya' \\
\hline 21. & berjalan & Manañjuy & $\approx$ & manañjuy \\
\hline 22. & bintang & Bintay & $\approx$ & bintay \\
\hline 23. & bulan & Bulan & $\approx$ & bulan \\
\hline 24. & bulu & Bulu & $\approx$ & bulu \\
\hline 25. & bunga & Kambay & $\approx$ & kambay \\
\hline 26. & bunuh & muno' & $\approx$ & munu \\
\hline 27 & buruk & $\begin{array}{l}\text { burok, } \\
\text { bewan } \\
\text { (bau) }\end{array}$ & $\approx$ & buruk \\
\hline
\end{tabular}


Jamzaroh

\begin{tabular}{|c|c|c|c|c|c|c|c|c|c|}
\hline 28 & Burung & Buroy & $\approx$ & buroy & 61. & jauh & kejaw & $\approx$ & kejaw \\
\hline 29. & cacing & Cacip & $\approx$ & cacin & 62. & kaki & payi' & $\approx$ & pay \\
\hline 30. & daging & Dagin & $\approx$ & dagin & 63. & $\begin{array}{l}\text { kami, } \\
\text { kita }\end{array}$ & Itah & $\approx$ & itah \\
\hline 31. & dan & dayan & $\approx$ & dayan & 64. & kamu & Ikaw & $\approx$ & ikaw \\
\hline 32. & danau & Danaw & $\approx$ & danaw & 65. & kepala & Takuluk & $\approx$ & takuluk \\
\hline 33. & darah & daha' & $\approx$ & daha & 66. & kiri & Mañambil & $\approx$ & sambil \\
\hline 34. & datang & Dumah & $\approx$ & dumah & 67. & kuning & bahenda' & $\approx$ & bahcnda' \\
\hline 35. & dengan & dəクan & $\approx$ & deyan & 68. & langit & Layit & $\approx$ & layit \\
\hline 36. & dengar & Hinin & $\approx$ & hinin & 69. & laut & Laut & $\approx$ & lawut \\
\hline 37. & di dalam & $\begin{array}{l}\text { hung } \\
\text { handalem }\end{array}$ & $\approx$ & si huway & 70. & lelaki & hatuwe' & $\approx$ & hatuwe \\
\hline 38 & dua & $d u w \varepsilon^{\prime}$ & $\approx$ & $d u w \varepsilon$ & 71. & licin & Lisin & $\approx$ & malisen \\
\hline 39. & duduk & Munduk & $\approx$ & munduk & 72. & lima & $\lim \varepsilon^{\prime}$ & $\approx$ & $\lim \varepsilon$ \\
\hline 40. & ekor & Buntut & $\approx$ & $\begin{array}{l}\text { kupan, } \\
\text { buntut }\end{array}$ & 73. & ludah & luja' & $\approx$ & luja \\
\hline 41. & empat & Epat & $\approx$ & cpat & 74. & lutut & Itut & $\approx$ & tut \\
\hline 42. & engkau & Ikaw & $\approx$ & ikaw & 75. & main & Usikan & $\approx$ & bausikan \\
\hline 43. & gali & Dali & $\approx$ & yali & 76. & makan & Kuman & $\approx$ & kuman \\
\hline 44. & garam & Uyah & $\approx$ & wyah & $\begin{array}{l}77 . \\
78 .\end{array}$ & $\begin{array}{l}\text { malam } \\
\text { mata }\end{array}$ & $\begin{array}{l}\text { malezm } \\
\text { mati' }\end{array}$ & $\begin{array}{l}\approx \\
\approx\end{array}$ & $\begin{array}{l}\text { malem } \\
\text { mate }\end{array}$ \\
\hline 45. & garuk & maygayaw & $\approx$ & gayaw & 79. & matahari & Matanandaw & $\approx$ & $\begin{array}{l}\text { matanand } \\
\text { aw }\end{array}$ \\
\hline 46. & $\begin{array}{l}\text { gemuk } \\
\text { lemak }\end{array}$ & sepst & $\approx$ & basepst & 80. & mati & $\begin{array}{l}\text { matEy, } \\
\text { malihi }\end{array}$ & $\approx$ & $\begin{array}{l}\text { matcy, } \\
\text { malihi' }\end{array}$ \\
\hline 47. & gigi & kasing' & $\approx$ & kasine & 81. & merah & Bahanday & $\approx$ & bahanday \\
\hline 48. & gunung & Gипип & $\approx$ & gunuџ & 82. & minum & Mihop & $\approx$ & mihup \\
\hline 49. & hantam & Hantam & $\approx$ & hantam & 83. & muntah & muta' & $\approx$ & muta' \\
\hline 50. & hati & atcy & $\approx$ & atcy & 84. & nama & Daran & $\approx$ & aran \\
\hline 51. & hidung & Uruy & $\approx$ & uruy & 85. & napas & tahansey & $\approx$ & tahansey \\
\hline 52. & hidup & belum & $\approx$ & babslum & 86. & orang & Uluh & $\approx$ & uluh \\
\hline 53. & hijau & Hijaw & $\approx$ & hijaw & 87. & panas & $\begin{array}{l}\text { lasu', } \\
\text { balasu' }\end{array}$ & $\approx$ & $\begin{array}{l}\text { lasu, } \\
\text { balasu' }\end{array}$ \\
\hline 54. & hujan & Ujan & $\approx$ & ujan & 88. & panjang & Panjay & $\approx$ & panjay \\
\hline 55. & ikan & Lauk & $\approx$ & lauk & 89. & pasir & Pasir & $\approx$ & pasir \\
\hline 56. & isteri & sawe & $\approx$ & sawe & 90. & pegang & Himbin & $\approx$ & imbiy \\
\hline 57. & jahit & Jahit & $\approx$ & jahit & 91. & pendek & Pandak & $\approx$ & pandak \\
\hline 58. & $\begin{array}{l}\text { jalan } \\
\text { (ber) }\end{array}$ & Nañjuy & $\approx$ & nañjuy & $\begin{array}{l}92 . \\
93 .\end{array}$ & peras & Hamis & $\approx$ & hamis \\
\hline 59. & jantung & Jantuy & $\approx$ & jantuy & 0 & punggu & & & \\
\hline 60. & jatuh & $\begin{array}{l}\text { labu', } \\
\text { gagar }\end{array}$ & $\approx$ & $\begin{array}{l}\text { labu, } \\
\text { baduruh }\end{array}$ & 95. & $\begin{array}{l}\text { ng } \\
\text { pusar }\end{array}$ & $\begin{array}{l}\text { Likur } \\
\text { puseR }\end{array}$ & $\approx$ & $\begin{array}{l}\text { likur } \\
\text { puser }\end{array}$ \\
\hline
\end{tabular}




\begin{tabular}{|c|c|c|c|c|}
\hline 96. & rambut & Balaw & $\approx$ & balau \\
\hline 97. & rumput & Uroy & $\approx$ & uru \\
\hline 98. & satu & $i j \varepsilon '$ & $\approx$ & $i j \varepsilon$ \\
\hline 99. & saya & Yaku & $\approx$ & yaku \\
\hline 100. & sayap & Palapas & $\approx$ & palapas \\
\hline 101. & sedikit & Isut & $\approx$ & isut \\
\hline 102. & siang & tuhandaw & $\approx$ & handaw \\
\hline 103. & suami & bane & $\approx$ & bane \\
\hline 104. & sungai & suycy & $\approx$ & sūcy \\
\hline 105. & tali & Tali & $\approx$ & tali \\
\hline 106. & tanah & Pitak & $\approx$ & petak \\
\hline 107. & tangan & leye' & $\approx$ & leys' \\
\hline 108 & telinga & Pindiy & $\approx$ & pindiy \\
\hline 109. & telur & hantelu' & $\approx$ & hantelul \\
\hline 110. & tertawa & tatawe' & $\approx$ & tatawe \\
\hline 111. & tidur & mantiruh & $\approx$ & tiruh \\
\hline 112. & tongkat & tujkct & $\approx$ & tuyket \\
\hline 113. & tua & Bakas & $\approx$ & bakas \\
\hline 114. & tulang & Tulay & $\approx$ & tulay \\
\hline 115. & tua & Bakas & $\approx$ & bakas \\
\hline 116. & tulang & Tulay & $\approx$ & tulay \\
\hline 117 & ibu & Umay & $\approx$ & uma \\
\hline 118 & kaki & payi' & $\approx$ & pay \\
\hline
\end{tabular}

\subsection{Pasangan Kata yang Mirip}

Pasangan kata yang mirip adalah pasangan kata yang mirip secara fonetis dalam posisi artikulasi yang sama. Pasangan yang mirip ini ditemukan karena adanya persamaan fonologi yang dimiliki oleh kedua bahasa yang diperbandingkan. Pasangan yang mirip ini memiliki perbedaaan yang bisa dijelaskan. Berikut ini adalah pasangan kata dalam bahasa yang mirip.
Tabel 6

\section{Pasangan Kata yang Mirip}

\begin{tabular}{|c|c|c|c|c|}
\hline No. & Glos & Barangas & & Bakumpai \\
\hline 1. & ayah & bapa' & $\approx$ & apa \\
\hline 2. & bakar & inosol & $\approx$ & mapuy, tusul \\
\hline 3. & banyak & $a^{\prime} a r i^{\prime}$ & $\approx$ & are \\
\hline 4. & bibir & Biwih & $\approx$ & biwih \\
\hline 5 & bilamana & parcyya' & $\approx$ & hamparcyya \\
\hline 6. & buah & bua' & $\approx$ & buwa' \\
\hline 7. & di dalam & $\begin{array}{l}\text { hung } \\
\text { handalem }\end{array}$ & $\approx$ & si huway \\
\hline 8. & daun & dawun & $\approx$ & dawen \\
\hline 9. & dekat & tokep & $\approx$ & tukep \\
\hline 10. & ibu & Umay & $\approx$ & uma \\
\hline 11. & itu & $t \varepsilon^{\prime}$ & $\approx$ & jite \\
\hline 12. & kaki & payi' & $\approx$ & pay \\
\hline 13. & kanan & $\begin{array}{l}\text { sila } \\
\text { mantau' }\end{array}$ & $\approx$ & gantau \\
\hline 14. & laut & Laut & $\approx$ & lawut \\
\hline 15. & lidah & jila' & $\approx$ & jela \\
\hline 16. & lihat & $i t \varepsilon$ & $\approx$ & gite \\
\hline 17. & lutut & Itut & $\approx$ & tut \\
\hline 18. & mata & $m a t i^{\prime}$ & $\approx$ & mate \\
\hline 19. & mulut & nanama' & $\approx$ & $n a m \varepsilon^{\prime}$ \\
\hline 20. & nama & Daran & $\approx$ & aran \\
\hline 21. & pegang & himbiy & $\approx$ & Imbiy \\
\hline 22. & perempuan & bawe & $\approx$ & bawi' \\
\hline 23. & rambut & Balaw & $\approx$ & balau \\
\hline 24. & rumput & Uroy & $\approx$ & uru \\
\hline 25. & siapa & cwch & $\approx$ & yawch \\
\hline 26. & tetek & tuso' & $\approx$ & tusu \\
\hline 27 & tiga & telo' & $\approx$ & telu \\
\hline
\end{tabular}

\subsection{Perubahan Bunyi}

Dari data-data yang ditemukan, dapat dikatakan bahwa kesepadanan itu dimungkinkan karena adanya pengaruh 
Jamzaroh

perubahan bunyi tertentu dengan fonemfonem lainnya dalam sebuah segmen. Perubahan ini dapat bersifat teratur maupun tidak teratur. Keteraturan menunjukkan korespondensi antarbahasa sekerabat.

\subsubsection{Pelemahan dan Penguatan Bunyi}

Crowley (1997:37--38) menyebutkan bahwa jika terjadi perubahan fonetis pada bahasa sekerabat, perubahan itu adalah dari 'kuat' menjadi 'lemah' dan dari 'kuat' menjadi 'lemah'.

\section{Pelemahan bunyi vokal}

Perubahan vokal yang terjadi dari bunyi vokal [i]-[ع], dan bunyi [u]-[o], merupakan pelemahan bunyi karena bunyi [i] dan [u] lebih kuat daripada $[\varepsilon]$, dan bunyi $[\mathrm{o}]$, sedangkan bunyi $[\mathrm{o}]-[\mathrm{u}]$ merupakan penguatan bunyi. Pada bahasa sekerabat, pelemahan bunyi dan penguatan bunyi yang teratur menunjukkan adanya korespondensi yang teratur pula.

\section{Tabel 7}

Pelemahan bunyi vokal $[i] \approx[\varepsilon]$ Bahasa Barangas dan Bakumpai

No. Goss Barangas Bakumpai

1. mata mati $^{\prime} \approx$ mate

2. takut mikch $\approx$ mekch

3. licin Lisin $\approx$ malisen

4. lidah jila' $\approx$ jela

5. istri bawe $\approx$ bawi

Dilihat dari bahasa Barangas, penguatan bunyi terjadi pada posisi ultima terbuka, yaitu [o] pada bahasa Bakumpai dan bunyi $[\mathrm{u}]$ pada pada bahasa
Bakumpai. Berikut bukti evidensi yang ditemukan.

\section{Tabel 8}

\section{Penguatan bunyi vokal [o]-[u] \\ Bahasa Barangas dan Bakumpai}

\begin{tabular}{|c|c|c|c|c|}
\hline No. & Glos & Berangas & & Bakumpai \\
\hline 1. & tetek & tuso' & $\approx$ & tusu \\
\hline 2. & tiga & telo' & $\approx$ & telu \\
\hline 3. & minum & mihop & $\approx$ & mihup \\
\hline 4. & rumput & uroy & $\approx$ & uru \\
\hline
\end{tabular}

Pelemahan dan penguatan bunyi konsonan $[b] \approx[w]$

Pelemahan dan penguatan bunyi juga terjadi pada bunyi konsonan pada bahasa Barangas dan bahasa Bakumpai.

\section{Tabel 9}

\begin{tabular}{|c|c|c|c|c|}
\hline \multicolumn{5}{|c|}{ Pelemahan bunyi konsonan $[\mathbf{b}] \approx[\mathbf{w}]$} \\
\hline No & Glos & Barangas & & Bakumpai \\
\hline 1 & besi & wasi & $\approx$ & besi \\
\hline 2 & babi & babuy & $\approx$ & bawi \\
\hline 3. & bibir & biwih & $\approx$ & biwih \\
\hline 4. & terbang & tarbay & $\approx$ & mantaraway \\
\hline
\end{tabular}

Pelemahan bunyi konsonan $[\mathrm{b}] \approx$ [w] pada bahasa Bakumpai dan bahasa Barangas bersifat tidak teratur. Perubahan bunyi [b] menjadi [w] menunjukkan adanya proses pelemahan bunyi (babi $\approx$ bawi, tarbay $\approx$ mantaraway, babuy $\approx$ bawi), sementara penguatan terlihat pada contoh wasi $\approx$ besi.

\section{Pelemahan bunyi [?] $\approx[]$}

Pelemahan bunyi [?] $\approx[$ ] atau $\Phi$ ' zero' bersifat fonetis. Artinya, pada hakikatnya, kedua kata yang dibandingkan hanya dibedakan dalam pengucapan. 
Tabel 10

Pelemahan bunyi

Bahasa Barangas dan Bakumpai

\begin{tabular}{|c|c|c|c|c|}
\hline N & Glos & Barangas & & Bakumpai \\
\hline & ayah & bapa' & $\approx$ & apa \\
\hline 2. & bilamana & parcyya' & $\approx$ & hamparcyya \\
\hline 3. & mati & mati' & $\approx$ & mate \\
\hline
\end{tabular}

Pelemahan bunyi fonetis juga terjadi dari [?] menjadi [ ] atau $\Phi$ 'zero'. Hal ini terjadi pada bunyi glotal pada bahasa Barangas ke bahasa Bakumpai. Meskipun demikian, kadang-kadang terjadi sebaliknya.

\subsubsection{Penghilangan Suku Kata di Awal Kata (Aphaeresis)}

Penghilangan atau pelesapan suku kata atau fonem di awal kata (aphaeresis) terjadi pada contoh berikut.

\section{Tabel 11}

Penghilangan bunyi awal kata Bahasa Barangas dan Bakumpai

\begin{tabular}{|c|c|c|c|c|}
\hline No. & Glos & Barangas & & Bakumpai \\
\hline 1. & bagaimana & $\begin{array}{l}\text { kakuweh } \\
\text { yo? }\end{array}$ & $\approx$ & kuwch \\
\hline 2. & lutut & Hitut & $\approx$ & Tut \\
\hline 3. & itu & Jitun & $\approx$ & tuh \\
\hline 4. & bapak & Bapa & $\approx$ & apa \\
\hline 5. & mulut & ñañama' & $\approx$ & $\tilde{n} a m \varepsilon$ \\
\hline 6. & banyak & a'ari' & $\approx$ & $\operatorname{arc}$ \\
\hline 7. & angkat & Himbiy & $\approx$ & imbiy \\
\hline 8. & bilamana & parcyya, & $\approx$ & hamparcyya \\
\hline 9. & kuku & Llu & $\approx$ & sillu \\
\hline 10. & kutu & Utu & $\approx$ & gutu \\
\hline
\end{tabular}

Penghilangan suku kata atau fonem konsonan di awal kata (aphaeresis) pada bahasa Bakumpai terjadi pada tabel 8 , nomor $1,23,4,5,6$, dan 7 dan pada bahasa Berangas terjadi pada nomor 8, 9, dan 10 .

\subsubsection{Penghilangan Suku Kata di Akhir Kata (Apokop)}

Penghilangan suku kata di akhir kata (apokop) antarbahasa sekerabat juga terjadi bahasa Bakumpai terhadap bahasa Barangas.

\section{Tabel 12}

\section{Penghilangan suku kata di akhir kata Bahasa Barangas dan Bakumpai}

$\begin{array}{lllll}\text { No. Glos } & \text { Barangas } & & \text { Bakumpai } \\ \text { 1. } & \text { ibu } & \text { umay } & \approx & \text { uma } \\ \text { 2. } & \text { kaki } & \text { payi } & \approx \text { pay } \\ \text { 3. } & \text { rumput } & \text { uroy } & \approx \text { uru }\end{array}$

\section{Penutup}

Kajian perbandingan antara bahasa Barangas dan bahasa Bakumpai telah mengungkap jati diri bahasa Barangas selama ini yang dianggap sebagai kreol. Ternyata, bahasa Barangas bukanlah kreol. Kedekatannya yang ditunjukkan dengan kesamaan kognat dalam beberapa jenis kata seperti kata ganti, kata bilangan, anggota tubuh, dll dengan bahasa Bakumpai menunjukkan bahwa mereka berasal dari rumpun bahasa Dayak Ngaju, meskipun tak dapat dipungkiri bahwa kedua bahasa, bahasa Barangas dan bahasa Bakumpai rentan 
terhadap pinjaman dari bahasa Melayu (Banjar).

Berdasarkan kajian leksikostatistik yang telah dilakukan dan mengacu pendapat Suyata (1995), kosakata dasar (basic vocabulary) dianggap sebagai warisan bersama dari bahasa protonya. Dengan demikian, kosakata tersebut mempunyai derajat retensi yang tinggi sepanjang masa. Bahasa Barangas dan bahasa Bakumpai memiliki kemiripan atau

\section{Daftar Pustaka}

Adelaar, K. A. (1994). Bahasa Melayik Purba: Rekonstruksi Fonologi dan Sebagian dari Leksikon dan Morfologi (1st ed.). Jakarta: Pusat Pembinaan dan Pengembangan Bahasa dan Universitas Leiden.

Antilla, R. (1972). An Introduction to Historical and Comparative Linguistic. New York: Macmillan.

Aritonang, B. (2002). Kosakata Dasar Swadesh di Provinsi Kalimantan Selatan. (B. Aritonang, Ed.) (1st ed.). Jakarta: Pusat Bahasa.

Bingan, Albert. A., Ibrahim, O. A. (1997). Kamus Dwi Bahasa Dayak Ngaju-Indonesia (2nd ed.). Palangkaraya: CV. Primal Indah.

Bynon, T. (1979). Historical Linguistics. Cambridge: Cambridge University Perss. kognat atau derajat retensi sebesar $75 \%$. Hal ini berarti bahwa kedua bahasa tersebut memiliki kerabat yang sangat dekat. Artinya, kedua bahasa memiliki warisan bersama (retensi) dari bahasa protonya atau bahasa induknya.

Campbell, L. (1998). Historical Lingusitics: An Introduction. Edinburgh: Edinburgh Uniersity Press.

Collins, J. T. (2005). Bahasa Melayu Bahasa Dunia: Sejarah Singkat (1, Agustus ed.). Jakarta: Yayasan Obor Indonesia.

Crowley, T. (1997). An introduction to Historical Linguistics (3d ed). Melbourne: Oxford University Press.

Fernandez, I. Y. (1995). Pengelompokkan Makro dan Mikro dalam Kajian Linguistik Secara Diakronis. Mumaniora, 1(LHK), 25--33.

https://doi.org/https://doi.org/10.22 146/jh.1986

Fernandez, I. Y. (1996). Relasi Historis Kekerabatan Bahasa Flores: Kajian Linguistik Historis Komparatif terhadap Sembilan 
Bahasa di Flores (1st ed.). Ende: Nusa Indah.

Hapip, A. D. et. al. (1984). Struktur Bahasa Barangas. Jakarta.

Hudson, Alfred, B. (1967). The Barito Isolect in Borneo. Departement of ASia Studies Cornell Universita.

Jahdiah, Yayuk, R., \& Wahdanie. (2012). Bahasa Daerah Kalimantan Selatan. Banjarbaru: Balai Bahasa Provinsi Kalimantan Selatan.

Kawi, D. (1985). Kamus Bakumpai Indonesia. (S. T. Suratman, Ed.) (1st ed.). Jakarta: Pusat Pembinaan dan Pengembangan Bahasa.

Keraf, G. (1991). Linguistik Bandingan historis (2nd ed.). Jakarta: Gramedia Pustaka Utama.

Klinkert. (1918). MaleischNederlandsch Zakwoordenboek. Leiden: N.V. Boekhandel en Drukkerij.

Mahsun. (2011). Metode Penelitian
Bahasa: Tahapan Strategi, Metode, dan Tekniknya (Ed. Revisi). Jakarta: Rajawali Pers.

Misrita. (2016). Relasi Historis Enklave Bakumpai di Marabahan, Kalimantan Selatan dan di Buntok, Kalimantan Tengah: Kajian Linguistik Diakronis. Jurnal Bahasa, Budaya, Dan Sastra: Komunitas Daun Lontar, Vol.3, No(Linguistic), 376.

Suyata, P. (1995). Dari Leksiostatistik ke Grotokronologi. Humaniora, I, 69--76. https://doi.org/DOI: https://doi.org/10.22146/jh.627

Wolff, J. (1988). "The Conribution of Banjarmasin Malay to The Reconstruction of Proto Malay". Rekonstruksi dan Cabang-Cabang Bahasa Melayu Induk. Kuala Kumpur: Dewan Bahasa dan Pustaka.

Yayuk, R. (2009). Relasi Kekerabatan Bahasa Banjar dan Bahasa Bakumpai. Universitas Lambung Mangkurat. 